\title{
Hoofd-halschirurgie en -oncologie tot over de grenzen
}

Citation for published version (APA):

Tan, B. (2017). Hoofd-halschirurgie en -oncologie tot over de grenzen. Maastricht University. https://doi.org/10.26481/spe.20170929bt

Document status and date:

Published: 29/09/2017

DOI:

$10.26481 /$ spe.20170929bt

Document Version:

Publisher's PDF, also known as Version of record

\section{Please check the document version of this publication:}

- A submitted manuscript is the version of the article upon submission and before peer-review. There can be important differences between the submitted version and the official published version of record.

People interested in the research are advised to contact the author for the final version of the publication, or visit the DOI to the publisher's website.

- The final author version and the galley proof are versions of the publication after peer review.

- The final published version features the final layout of the paper including the volume, issue and page numbers.

Link to publication

\footnotetext{
General rights rights.

- You may freely distribute the URL identifying the publication in the public portal. please follow below link for the End User Agreement:

www.umlib.nl/taverne-license

Take down policy

If you believe that this document breaches copyright please contact us at:

repository@maastrichtuniversity.nl

providing details and we will investigate your claim.
}

Copyright and moral rights for the publications made accessible in the public portal are retained by the authors and/or other copyright owners and it is a condition of accessing publications that users recognise and abide by the legal requirements associated with these

- Users may download and print one copy of any publication from the public portal for the purpose of private study or research.

- You may not further distribute the material or use it for any profit-making activity or commercial gain

If the publication is distributed under the terms of Article $25 \mathrm{fa}$ of the Dutch Copyright Act, indicated by the "Taverne" license above, 
Dhr. prof.dr. I. Bing Tan Faculty of Health, Medicine and Life Sciences

Hoofd-halschirurgie en -oncologie tot over de grenzen 
Mevrouw de rector magnificus, zeer geachte decaan, Leden van de raad van bestuur, collegae, familie en vrienden

Vandaag wil ik samen met $u$ in de 45 minuten die mij gegeven zijn de grenzen van mijn vak, de hoofd-halschirurgie en oncologie exploreren.

Het woord grens heeft voor mij altijd een bijzondere betekenis gehad. Niet in de laatste plaats omdat ik hier in Maastricht geboren ben en van kinds af aan heb geleefd dichtbij het drielandenpunt, dus omgeven door grenzen. Zelfs als je op zondag wat croissants wilde halen in België, dan liep je het risico dat je aan de grens werd aangehouden en je paspoort moest laten zien.

Een grens is een denkbeeldige scheidende lijn, bijvoorbeeld een staatkundige grens tussen twee landen, of een natuurlijke grens die samenvalt met een rivier of een bergketen, maar kan net zo goed de afbakening zijn tussen twee medische disciplines. Bij een grens moet je beslissen wat je gaat doen. Je kunt er overheen gaan bijvoorbeeld om je horizon te verbreden als verdieping voor je opleiding of om internationale samenwerkingsverbanden op te zetten. Maar je kunt ook terecht komen buiten de grenzen van de gevestigde behandelmethoden en soms ga je zelfs over de grens van andere disciplines heen, waardoor er of wrijving of juist een intensieve samenwerking kan ontstaan.

Mijn medische opleiding ben ik begonnen aan de Rijks Universiteit in Leiden, gevolgd door mijn specialisatie in de keel- neus- en oorheelkunde aan de Vrije Universiteit onder leiding van professor Snow.

Gezien mijn interesse in de oncologie en het beschikbaar komen van beurzen van KWF-kankerbestrijding voor klinische fellowships in de oncologie, had mijn opleider bedacht dat dit een uitgelezen kans voor mij zou zijn om mij verder te ontwikkelen in de hoofd-halschirurgie en oncologie. Het eerste jaar kon ik op de Vrije Universiteit doorbrengen, het tweede jaar in Frankrijk en het Antoni van Leeuwenhoek. Mijn eerste echte ervaring met werken over de grenzen begon dus in Frankrijk in het Institute Gustave Roussy in Villejuif bij Parijs onder leiding van dr. Richard en dr. Schwaab. De Franse slag bleek toch iets meer inhoud te hebben dan de uitdrukking suggereert. In dit instituut werd op het hoogste niveau de hoofd-halschirurgie bedreven met zeer geavanceerde operatietechnieken. Ik heb hier veel van kunnen leren en allerlei tips en tricks van zeer ervaren hoofd-halschirurgen mee gekregen. Op het gebied van teaching heb ik van mijn opleider dr. Schwaab mogen ervaren hoe belangrijk het is om soms hele operaties van het begin tot en met het sluiten minutieus 
te coachen om vervolgens de fellow weer stukken zelfstandig te laten opereren. Zijn liefde voor het vak en met name voor het opereren met bijna uitsluitend een mes heeft hij op mij overgebracht. Gevleugelde woorden als hij aan het opereren was waren altijd: "En daar word je nog voor betaald ook".

Het fellowship daarna in het Antoni van Leeuwenhoek heeft mijn ogen geopend. De essentie van multidisciplinair werken werd daar met de paplepel ingegoten. Het overleg en de samenwerking tussen de betrokken disciplines verliep moeiteloos waarbij steeds alleen het belang van de patiënt voorop stond. Deze manier van werken is een voorbeeld voor mij geworden. Vaak zie je dat de verschillende afdelingen aparte koninkrijkjes zijn, met ieder een eigen koning of koningin en uiteraard bijpassende agenda. Belangeloos tussen en met andere afdelingen kunnen samen werken is de sleutel tot goede en adequate patiëntenzorg.

Na mijn fellowship ben ik uiteindelijk in het Westeinde ziekenhuis in Den Haag terecht gekomen waar ik als B-opleider vele assistenten van de Vrije Universiteit heb mogen begeleiden. Daar heb ik in overleg met de Vrije Universiteit en samen met mijn collegae dr. Werkman en dr. Croll een oncologisch samenwerkingsverband kunnen opzetten. Het bleek mogelijk om ook op kleinere schaal met een gemotiveerd multidisciplinair team, goede patiëntgerichte zorg te bieden in nauwe samenwerking met de moederkliniek. Hoewel wij destijds over de grenzen zijn gegaan van wat de Nederlandse Werkgroep Hoofd-Hals Tumoren als wenselijk achtte is het uiteindelijk toch een geaccepteerde constructie geworden met nu 6 preferred-partner klinieken door Nederland die ieder intensief zijn verbonden met een van de academische hoofd-halscentra. Hoewel er binnen deze constructies goede en persoonlijker zorg wordt verleend is het de vraag of het gezien de relatieve zeldzaamheid van deze categorie patiënten niet wenselijker is om te streven naar meer concentratie in een beperkt aantal centra in lijn met de gedachte "higher volume, better outcome"

Ondanks het feit dat het werk in Den Haag mede door het brede palet en de zeer goede sfeer erg bevredigend was, bleek de combinatie van algemene KNO en hoofd-halschirurgie voor mij uiteindelijk niet te werken en toen ik de mogelijkheid kreeg om terug te keren op mijn favoriete plek, het Antoni van Leeuwenhoek in Amsterdam, was de keuze, zij het met pijn in het hart, snel gemaakt. 
Daar kwam ik vrijwel meteen in aanraking met internationale samenwerkingsverbanden. Door de grote rol die de hoofd-halsgroep speelde op het gebied van revalidatie na totale laryngectomie in al zijn aspecten, heb ook ik als onderdeel van het team vele voordrachten en cursussen in het buitenland mogen verzorgen. Door de ontwikkeling van een eigen stemprothese waarbij professor Hilgers een cruciale rol heeft gespeeld was het voor onze groep mogelijk om internationaal toonaangevend te worden op het gebied van de revalidatie na totale laryngectomie. Een ander internationaal samenwerkingsverband kwam tot stand in het kader van een nieuwe behandeling, de zogenaamde PhotoDynamische Therapie (PDT) Dit is een non-invasieve behandelmodaliteit, waarbij gebruik wordt gemaakt van een lichtgevoelige stof, een photosensitizer en laserlicht met een speciale golflengte. Vier phototoxische reacties zorgen voor een massale weefsel destructie in het belichte gebied. Het Antoni van Leeuwenhoek had al van oudsher veel belangstelling voor deze behandelmethode en er was al veel preklinisch onderzoek verricht. Toen ik in 1996 in het Antoni van Leeuwenhoek terugkwam starten net de internationale klinische trials met PDT. Een mooi voorbeeld van translationeel onderzoek waarbij het labwerk uiteindelijk ten goede komt aan de patiënt. Deze behandeling had ook alles met grenzen te maken. Het was een nieuwe behandelmethode die gebruikt werd naast de traditionele behandelingen zoals chirurgie en radiotherapie met name voor de kleine oppervlakkige mond- en keelholte tumoren. Aanvankelijk is er veel kritiek geweest op deze "fancy behandelmethode", met name omdat het gebruikt werd in plaats van effectieve conventionele behandelmethoden met een bewezen effectiviteit. Hierbij werd destijds voorbijgegaan aan het feit dat PDT heel weinig schade geeft op de lange termijn en dat PDT ook gebruikt kan worden voor de behandeling van recidieven en multipele primaire tumoren. PDT kan namelijk nog gebruikt worden na radiotherapie en/of chirurgie en kan ook worden herhaald. Beperkingen zijn er bij PDT natuurlijk ook en die zitten met name in de diepte penetratie van maximaal $1 \mathrm{~cm}$ zodat de tumoren niet dikker mogen zijn dan $5 \mathrm{~mm}$. Door het licht met behulp van glasvezels in de tumor zelf te brengen hebben we deze beperking op kunnen lossen. Veel werk is er gedaan door mijn PDT-collega dr. Baris Karakullukcu die deze vorm van PDT, de zogenaamde interstitiële PDT (iPDT) verder heeft gestandaardiseerd. Momenteel loopt er een vervolg promotieonderzoek van Tessa van Doeveren in samenwerking met het Erasmus medisch centrum in Rotterdam, waarbij de toepassingen van PDT worden onderzocht bij de behandeling van het recidief neusbijholte carcinoom.

Wat ook mooi was aan de begintijd van de PDT was dat er door de internationale multicenter studies een groep ontstond van principal 
investigators van de deelnemende centra uit de diverse landen. Als de studie afgerond was werden we met alle principal investigators door de sponsor opgesloten in een zeer aangenaam doch afgelegen hotel totdat er een manuscript klaar was. Dat was zo inspirerend dat niet alleen het artikel snel vorm kreeg, maar dat ook met dezelfde snelheid de vloeibare voorraden van het hotel uitgeput raakten. Ik denk overigens dat dergelijke constructies tegenwoordig niet meer toegestaan zijn, maar effectief en nuttig voor de internationale teamspirit was het wel.

\section{Werken over de grenzen}

Een ander voorbeeld van een internationale werkzaamheden is de samenwerking met Indonesië. In 1999 kreeg ik de kans om via kleine projecten, geïnitieerd door KWF Kankerbestrijding ter ere van haar vijftigste verjaardag, een samenwerking op te bouwen met Indonesië. Dit was eerst een lokaal initiatief in het academisch ziekenhuis in Yogyakarta met uitwisselingsprojecten tussen dokteren en verpleegkundigen. Grootse plannen om een afdeling hoofd-halschirurgie op te zetten bleken al snel niet realistisch. Om een beter inzicht te krijgen over wat er zich achter de gordijnen afspeelde heb ik in 2001 mijn sabbatical van 6 maanden in Yogyakarta doorgebracht. Beperkte radiotherapie capaciteit, financiële problemen van de patiënten en moeizame multidisciplinaire samenwerking maakten dat hoofd-halschirurgie vanaf de basis moest worden opgebouwd. Door te focussen op het nasopharynx carcinoom, daar de 4e meest voorkomende tumor bij mannen, kon een begin worden gemaakt met de multidisciplinaire benadering. Bij de behandeling van deze vorm van kanker heb je namelijk intensief contact nodig met je patholoog, radioloog, radiotherapeut en natuurlijk de internistoncoloog. Belangrijk was ook om vanaf het begin betrouwbare data te genereren, want er was geen goede data registratie zodat een indruk over behandelresultaten niet voorhanden was.

Dankzij een intensieve samenwerking met het onderzoeksteam in Yogyakarta onder leiding van Professor Sofia Mubarika Haryana ontstond een zeer vruchtbare samenwerking. Als erkenning voor deze wetenschappelijke activiteiten werd in 2007 mijn visiting professorship omgezet in een full professorship met een leerstoel in de hoofd-halsoncologie en -chirurgie aan de Gadjah Mada Universiteit in Yogyakarta. Dat was bijzonder omdat voor het eerst in de geschiedenis van deze universiteit een niet-Indonesiër op deze positie is benoemd. 
Met name de intensieve samenwerking met professor Middeldorp uit het VUMC heeft ervoor gezorgd dat er ook een uitgebreide basale researchlijn ontstond, waarbij met behulp van Epstein-Barr Virus gerelateerde markers gekeken kon worden naar vroegdiagnostiek en screening van nasopharynx kanker en zelfs nieuwe behandelmethoden met behulp van cytolitische virus activatie konden worden uitgetest.

Vele onderzoeksprojecten zijn in deze periode ontstaan en uitgegroeid tot 7 proefschriften. Uit de data die we in Yogyakarta hebben verzameld blijkt dat er vaak onacceptabele wachttijden waren voor de radiotherapie en dat de behandelresultaten van nasopharynx kanker erg achterliepen in vergelijking met de internationale literatuur. De vele problemen die de behandeling van deze vorm van kanker oproepen zijn goed in kaart gebracht door de promovendi en hieruit zijn ook een aantal oplossingen naar voren gekomen. Het creëren van meer awareness voor deze tumorsoort kan ertoe bijdragen dat patiënten eerder naar de huisarts gaan. En door de huisartsen beter te informeren, kan dit ervoor zorgen dat patiënten met een vroeger stadium van ziekte gediagnosticeerd kunnen worden. Het tekort aan radiotherapie faciliteiten is duidelijk aangetoond en er wordt momenteel hard gewerkt om het tekort ( 1 versneller voor 6 miljoen mensen) drastisch omlaag te brengen met het bouwen van nieuwe en uitbreiden van bestaande locaties. Aangezien we in onze studies veel patiënten met persisterende ziekte zagen na behandeling vroegen wij ons af of deze patiënten niet behandeld konden worden met PDT, waar inmiddels al ruime ervaring mee bestond in de mond en keelholte. In samenwerking met professor Levendag en professor Sterenborg uit Rotterdam en het team van het Center of Optical Diagnostics and Therapy (CODT) hebben we een nasopharynx applicator ontworpen en later gepatenteerd, waarmee een volledige belichting van de nasopharynx kon worden bereikt met sparen van kritieke structuren zoals het palatum molle. Cruciaal onderdeel van deze applicator bestond uit een stuk binnenband van mijn oude Puch.

Heike Nyst, een van de eerste promovendi, is samen met de fysicus Robert van Veen deze moeilijke studie begonnen in 2003 , ruim $12.000 \mathrm{~km}$ van huis en waarbij de eerste studiepatiënt vrijwel direct na de behandeling is overleden. Gelukkig bleek dit niet aan de behandeling was gerelateerd en mochten we van de medisch ethische commissie doorgaan met de studie. Uiteindelijk hebben we in twee studies goede resultaten kunnen aantonen. Gezien de nog steeds zeer lange wachttijden ligt het voor de hand om deze therapie ook te gaan gebruiken in de neoadjuvante setting, dus voorafgaande aan de 
definitieve chemo radiatie behandeling, ten einde de anders onvermijdelijke tumor progressie om te buigen in tumorreductie.

Los van deze activiteiten is er in Indonesië ook veel op landelijk educatief en organisatorisch niveau gebeurd. Toen in 2001 de naam van de Indonesische KNO-vereniging werd veranderd door het toevoegen van chirurgie van het hoofdhalsgebied heb ik met prof Bambang Hermani, destijds voorzitter van de KNO-vereniging vele discussies gehad over de noodzaak van een curriculum voor hoofd-halschirurgie en oncologie en het opzetten van een landelijk training programma. Met behulp van de bezielende hulp en leiding van dr. Marlinda Adham en professor Bambang Hermani kon er uiteindelijk een landelijk trainingsprogramma opgezet worden waaraan nu 13 universiteiten deelnemen.

Ook was het oprichten van een Indonesische Hoofd-Hals Werkgroep vanaf het begin onze grote wens. Zonder een dergelijke werkgroep is multidisciplinaire behandeling van patiënten met een hoofd-halstumor onmogelijk. In de praktijk bleek dit echter moeilijker dan we ons in eerste instantie hadden voorgesteld, want iedere afdeling leek wel een eigen koninkrijk te vormen en het leek aanvankelijk bijna onmogelijk om de grenzen te slechten en echt multidisciplinair te gaan werken. Uiteindelijk is het, met name door geduld en doorzettingsvermogen in 2013 toch gelukt om deze vereniging (de PERDOKLI) op te richten, net op tijd voor Indonesië om in 2014 lid te worden van de IFHNOS. De International Federation of Head and Neck Oncological Societies. De wenselijkheid en noodzaak van deze twee acties heb ik verwoord in mijn inaugurele rede aan de Gadjah Mada Universiteit op 13 December 2007 en het is mooi dat nu 10 jaar later deze wens blijkt te zijn uitgekomen. Indonesië speelt nu een belangrijke rol in de zuidoost Azië regio en is ook lid geworden van de Asian Society of Head and Neck Oncology de ASHNO en heeft afgelopen maart het ASHNO-congres op Bali georganiseerd. Dit zijn grote congressen waar veel internationale coryfeeën komen en die een Aziatische tegenhanger zijn geworden van de congressen van de American Head and Neck Society. Dr. Marlinda is afgelopen congres gekozen tot de president van de ASHNO. De intensieve samenwerkingsverbanden die er in de loop van de jaren zijn ontstaan hebben duidelijk hun vruchten afgeworpen.

Al 16 jaar nemen we, met een Nederlandse delegatie, deel aan de jaarlijkse hoofd- halsoncologie en chirurgie cursus in Bangkok. Het mooie van deze cursus is dat wij niet alleen samen met de Thaise dokters kunnen bijdragen aan de training van de KNO-artsen in opleiding uit de regio, maar dat Bangkok ook een trainingscentrum is geworden voor fellows uit Nederland, die daar hun vaardigheden in de reconstructieve chirurgie met microvasculaire 
transplantaten kunnen leren. Ook bestaan er al jarenlange teaching contacten met de universiteit van Kuala Lumpur waardoor we regelmatig fellows hebben gehad uit die regio.

Per 1 oktober dit jaar zal de eerste fellow uit Maleisië hier in het MUMC+ haar stage starten.

\section{Verdwaald over de grens}

Soms kun je je volledig verdwaald voelen als je over de grens alle gevoel voor richting verliest doordat je in een volledig vreemd landschap verzeild bent geraakt. Dit gevoel had ik toen ik in 1981 aan mijn opleiding tot KNO-arts begon en mij gevraagd werd door mijn collega professor Balm, destijds de oudste assistent, of ik zijn promotie onderzoekslijn wilde voortzetten. Collega Balm was na zijn ervaringen bij de bloedbank waar hij zijn militaire dienstplicht had vervuld, geïntrigeerd geraakt door de immunologie bij hoofd-halstumoren. Ik was natuurlijk vereerd met dit voorstel en niet gehinderd door enige kennis heb ik natuurlijk ja gezegd. Het gevolg was dat ik 4 jaar door het gebied van de immunologie heb gedwaald waarbij het onderzoek steeds meer raakvlakken kreeg met de nieuwste hypes in de wetenschap van die tijd zoals monoclonale antilichamen, retrovirussen, oncogenen en nog veel meer, te veel om te snappen voor een eenvoudige KNO-arts in opleiding. Door de goede begeleiding en ook de intensieve hulp van collega dr. Drexhage als klinisch immunoloog, ben ik niet volledig verdwaald. We hebben kunnen aantonen dat de afweer bij hoofd-halstumoren wordt geremd door een laagmoleculaire stof, het P15E. We dachten toen nog simpel, dat we dan alleen iets moesten verzinnen om dit stofje te neutraliseren en dat het kankerprobleem dan was opgelost. Helaas zat het allemaal iets ingewikkelder in elkaar en wist destijds niemand precies hoe het mechanisme werkte. Nu de enorme hype rond immunotherapie is losgebarsten denk ik dat deze onderzoekslijn destijds zeker van visie getuigde.

Het laat ook zien dat het kijken over de grenzen van andere specialismen vruchtbare samenwerking projecten kan opleveren. Dit wordt tegenwoordig ook weer duidelijk door de intensieve samenwerking die is ontstaan in het Antoni van Leeuwenhoek tussen de afdelingen hoofd-hals chirurgie, medische oncologie en radiotherapie. Dr. Lotje Zuur heeft zich als groepsleider in het NKI-research gebouw geprofileerd op het gebied van immunologie bij hoofd hals tumoren en de eerste klinische trial wereldwijd opgezet waarbij een combinatie van aPD1 en aCTLA4 c.q. immunotherapie wordt toegediend in de zogenaamde neo-adjuvante setting, dus waarbij deze therapie wordt ingezet voorafgaande aan uitgebreide chirurgie voor een maligniteit van de mond- of 
keelholte. Het doel van deze toevoeging van immunotherapie aan chirurgie is tumorreductie te bereiken door het tumor-specifieke afweersysteem van de patiënt te verbeteren en daarmee naar verwachting ook de prognose. De zogenoemde IMCISION trial. De hoofd hals werkgroep van het MUMC+ doet mee met deze studie, aanvankelijk alleen door patiënten te includeren, maar na het afronden van de haalbaarheidsstudie zullen wij ook patiënten in Maastricht gaan behandelen met deze combinatie behandeling.

De belangstelling voor de immunotherapie is breed aanwezig in het MUMC+ en op dit moment zijn we in samenwerking met het Antoni van Leeuwenhoek, ook onder leiding van collega Zuur, een onderzoekstraject gestart waarbij gekeken wordt naar de combinatie van immunotherapie en Photodynamische therapie. Dit wordt een MUMC+ promotie waarbij uiteraard ook de afdeling medische oncologie en radiotherapie van ons ziekenhuis nauw betrokken zullen zijn.

Ook voor onze projecten in Azië lijkt de combinatie van Photodynamische therapie met immunotherapie en met name met de checkpoint inhibitors zoals anti PD1 en anti PDL1 voor de hand te liggen. Door de zeer lange wachttijden voorafgaand aan de radiotherapeutische behandeling lijken innovatieve ideeën noodzakelijk teneinde tumorprogressie tijdens de wachttijd te beperken.

\section{Tot over de grenzen??}

Hoofd Hals tumoren zijn moeilijk te behandelen. De tumoren hebben vaak agressieve groei kenmerken, zitten in een zeer kwetsbaar gebied, vlakbij de hersenen, ogen en ruggemerg en de consequenties van de behandeling zijn vaak groot, $\mathrm{mn}$ op het gebied van functionaliteit zoals eten, drinken, praten, maar ook op het gebied van cosmetiek. Helaas lopen we dus regelmatig aan tegen de grenzen van ons kunnen. Daarmee kom ik op het laatste wat ik nog wil zeggen over grenzen. Hoever moeten we gaan met het behandelen van onze patiënten.

Niet zelden bekruipt mij het gevoel dat we over grenzen heen gaan. Het belangrijkste wat ik geleerd heb in al die jaren is het belang van het naleven van de eed van Hippocrates. "Do no harm". Als je kijkt naar de vaak fragiele patiënten met veel co-morbiditeit en de zeer slechte prognose dan vraag je je regelmatig af, wat is het beste voor deze patiënt en dringt het wel echt door welke gevolgen de grote chirurgie of intensieve radio- en chemotherapie zal hebben. 
Belangrijk is om eerlijk en duidelijk te zijn tegen de patiënt. Als we kijken hoe eenvoudig het leven in elkaar steekt, dan weten we dat we op een mooie dag geboren worden, maar dat er ook eens een dag komt waarop we zullen overlijden. Alleen al het besef van dat laatste en de acceptatie daarvan maken dat er ruimte komt om na te denken hoe je als patiënt het laatste stuk van je leven wilt inrichten. Je kunt er na uitgebreide voorlichting voor kiezen om tot het gaatje te gaan, dus alles te doen om zo lang mogelijk te leven of je kunt ervoor kiezen om nog zo lang mogelijk de tijd die er nog rest zo goed mogelijk door te brengen en toe te werken naar een waardig levenseinde. De vraag van de patiënt van hoe lang heb ik nog, is makkelijk te beantwoorden. Ik zeg altijd "tussen de 5 minuten en 50 jaar en zelfs dat is niet zeker". En omdat dit niet zeker is en niemand garanties kan geven over hoeveel tijd je nog wel hebt is het zaak om vanaf dat moment een twee sporen beleid te volgen: "Prepare for the worst en hope for the best". Dus begin met het bespreekbaar maken van de dood, het opruimen van de zolderkamer van je leven en het regelen van praktische zaken. Dat geeft veel lucht en uiteindelijk stap je hiermee ook letterlijk over de deadline heen. Het maakt dan niet meer uit hoe lang je nog leeft, iedere dag erbij is winst. Ik heb met veel patiënten deze discussies gevoerd en velen hebben aangegeven dat deze periode een van de waardevolste uit hun leven was. Alles waar je je druk over hebt gemaakt blijkt niet relevant te zijn. Alleen de echt belangrijke en dierbare zaken blijven over. Bij het opstellen van allerlei zorgpaden en sneldiagnostiek trajecten denk ik dat het heel belangrijk is als aan dit aspect meer aandacht wordt besteed. We moeten ervoor zorgen dat patiënten geen spijt krijgen van de vaak hele grote en kostbare diagnostische procedures en aansluitende ingrepen die ze met goede voorlichting nooit zouden hebben gekozen. Een extra traject waarin aandacht wordt besteed aan deze patiëntengroep kan veel leed maar ook veel kosten besparen. Ik ben heel blij dat we hier in het MUMC+ nu samen met het consultatieteam palliatieve zorg en ouderen geneeskunde een project hebben opgestart, advanced care planning, waarin we extra aandacht gaan besteden aan deze kwetsbare patiëntengroep.

\section{De toekomst}

Ook de jaren die mij nog resten in mijn MUMC-carrière vliegen voorbij. Het is voor mij dus belangrijk om te bepalen aan welke doelen, die we als afdeling hoofdhals-chirurgie hebben gesteld, ik nog mijn bijdrage kan leveren.

Als belangrijkste taak zie ik mijn aandeel in de opleiding van Laura Baijens tot nieuwe hoofd-halschirurg. Zij zal met haar kennis over dysfagie, een onderwerp waarin zij een internationaal erkend expert is, haar ervaring met de 
moeilijke luchtwegen, haar chirurgische vaardigheden en haar grote theoretische kennis als internationale IFHNOS-fellow een zeer grote bijdrage kunnen leveren voor de Maastrichtse Hoofd-Hals Werkgroep. Het komt niet vaak voor dat een fellow al 10 jaar staflid is en dan toch nog de stap neemt om een nieuwe carrière te beginnen als hoofd-halschirurg.

Het opzetten van een centrum voor PDT in het MUMC+ is ook een van die doelen. Hierbij mogen we niet uit het oog verliezen dat het initiëren van nieuwe behandelmethoden een investering kost, niet alleen aan apparatuur, maar vooral ook aan ondersteuning in de logistiek. Tot nu toe hebben we enkele patiënten in het MUMC+ kunnen behandelen met deze therapie, maar daarbij hebben we teveel moeten leunen op de logistiek en ondersteuning van het Antoni van Leeuwenhoek. Dat is in de beginfase goed te doen, maar zal door het MUMC+ moeten worden overgenomen op de langere termijn. Hetzelfde geldt voor de schildwachtklier procedure, waarbij bij patiënten met een melanoom in het hoofdhalsgebied of patiënten met een plaveiselcelcarcinoom van de mondholte met een klinisch negatieve hals, de halsklieren van de eerst drainerende stations worden verwijderd. Dit heeft als doel een betere stadiëring te kunnen bewerkstelligen en hopelijk ook betere prognose. Ook voor deze procedure geldt dat we inmiddels enkele patiënten hebben behandeld, maar dat dit nog geen routine is geworden. Deels door de gecompliceerde logistiek maar ook deels door gebrek aan operatietijd. Toch zullen we in de nabije toekomst deze techniek moeten incorporeren in ons behandelarsenaal om in lijn te blijven met de meest recente ontwikkelingen en protocollen. Deelname aan multicenter trials zoals de Imcission trial, de Luna-studie en de hoofd-halsrevalidatie studie en het opzetten van gezamenlijke studies zoals de het immunoPDT-project zullen op den duur een positieve stimulans geven aan de Maastrichtse werkgroep. Het eerdergenoemde project over advanced care planning, waarbij we de kwetsbare patiënten met een slechte prognose intensiever willen informeren over de voor- en nadelen van de behandeling is een van mijn prioriteiten en ik hoop dat met de samenwerking met het palliatieve team en de ouderengeneeskunde een dergelijk initiatief levensvatbaar zal zijn. Het opleiden van buitenlandse fellows is een dankbare taak en goed voor de internationale contacten van onze werkgroep.

Verder wil ik in de resterende tijd die ik nog heb in Maastricht een actieve bijdrage leveren aan deze werkgroep om de grenzen tussen de verschillende disciplines zoveel mogelijk te slechten en te komen tot een harmonische hoofd-hals werkgroep waarbij maar een belang bestaat, namelijk dat van onze patiënten. 


\section{Dankwoord}

Als eerste wil ik het college van decanen van het MUMC+ bedanken voor het in mij gestelde vertrouwen. Het is bijzonder dat ik hier nu sta. In feite is mijn college Martin Lacko de grote aanstichter. Ik had een paar PowerPoint dia's nodig van Martin en na wat over en weer gemaild en gebeld te hebben zei Martin: "Kom ze maar halen, want je moet gewoon hier komen werken". Ik had nog nooit bedacht dat ik ooit het Antoni van Leeuwenhoek zou verlaten. Ik had daar fantastische collegae, in een geweldig stimulerende omgeving. Maar wat ik niet bedacht had was dat ik nog maar twee jaar te gaan had voor mijn pensioen en in feite ongemerkt al aan de afbouwfase van mijn carrière was begonnen. Het aanbod van Bernd Kremer om naar Maastricht te komen om voor een periode van vijf jaar de hoofd-halschirurgie en oncologie te komen versterken als opleider van de fellow en voor het invoeren van enkele innovaties zoals PDT en schildwachtklier procedures werd opeens heel aantrekkelijk en ik zie het nu als de kers op de taart van mijn carrière. Het voelt goed om weer terug te zijn op mijn geboortegrond. In Indonesië noemen ze dat Pulang Kampung.

Ik dank de afdeling KNO voor de warme ontvangst hier in het zuiden. Ik beschouw het als een eer dat ik Laura Baijens als fellow mag begeleiden die met haar vele en bijzondere kwaliteiten de ideale persoon is om op te leiden. Dank aan de leden van de hoofd-halswerkgroep en in het bijzonder aan onze voorzitter Erik Dik voor het enthousiasme en de constructieve samenwerking. Mijn collegae uit Amsterdam voor de jarenlange vriendschap en samenwerking. Ik ben erg blij dat ik nog mijn nul-aanstelling in het Antoni van Leeuwenhoek heb en dat we kunnen samenwerken met steeds meer projecten!

Op zo'n dag als deze denk ik ook terug aan mijn ouders. Tenslotte ben ik een geboren en getogen Maastrichtenaar en het is voor mij bijzonder dat er soms weer patiënten zijn die heel voorzichtig vragen: $u$ bent toch geen zoon van $\mathrm{dr}$. Tan?? Dé Dokter Tan van vroeger??

Graag wil ik ook mijn moeder memoreren, hoe zij op haar knieën langs de Maastrichtse middelbare scholen is gekropen om te vragen of er nog iemand bereid was om haar onhandelbare zoon nog een kans te geven nadat ik weer eens van school was verwijderd.

Trots ben ik op mijn twee fantastische dochters die ook de liefde voor het medische vak hebben geërfd. Josephine als biochemicus die zich in het AMC gestort heeft op een promotieonderzoek naar de cholesterol huishouding en Katherine, die besloten heeft dat zij het hoger op wil zoeken. De schedelbasis is voor mij de grens, voor haar begint het pas daarboven. Zodoende heeft ze zich in het neurochirurgische promotieonderzoek gestort. 
En last but not least, Anne-Marie. Dank voor je liefde, je steun en stimulans om dit avontuur samen aan te gaan. Tijdelijk overgestapt naar een latrelatie genieten we volop van de afwisseling tussen de bruisende binnenstad van Amsterdam en de prachtige Limburgse heuvels verborgen tussen de grenzen waar het allemaal begonnen is. De best of two worlds.

Ik heb gezegd 